\title{
Evaluation of Cash Collection System on Financing without Collateral at PT. XYZ
}

\author{
Cut Nessa Cinthya \\ Accounting Department, Economic and Business Faculty \\ University of Indonesia Jakarta, \\ Indonesia \\ cutnessacinthya@yahoo.comline
}

\author{
Dr. Gede Harja Wasistha, CMA \\ Accounting Department, Economic and Business Faculty \\ University of Indonesia \\ Jakarta, Indonesia \\ wasistha@ui.ac.id
}

\begin{abstract}
To meet their ever-changing financial needs, people employ various strategies, such as credit financing. $\mathrm{PT}$. $\mathrm{XYZ}$ is a consumer finance company that offers financing without collateral (hire purchase). Hire purchase is significant unsecured financing offered when a consumer fails to pay, and the company has no guarantee whatsoever for the financing. Therefore, the accounts receivable must be well managed to reduce the risk of loss for the company. PT. XYZ's income statements reveal that the value of the company's bad debts continues to increase every year. Good internal control is needed to minimize the value of bad debts. This study aims to evaluate the internal controls in collecting receivables at the company, using risk management theory. This research uses descriptive qualitative method with case study approach. The data collection was carried out through observations and interviews. The results suggest that PT.XYZ can improve the standard operating procedure and internal control over its billing procedures.
\end{abstract}

Keywords—risk management, financing without collateral, credit, internal control system, billing receivable system, standard operating procedure

\section{INTRODUCTION}

\section{A. Background}

Indonesia's economic growth continues to show very positive developments in various areas and the increased economic growth is affecting the needs of the community [1]. In order to fulfill these needs, people can make purchases, leases, or financing on credit (Thomas, 2010). The increasing public demand for financial products has had a positive impact on the development of financial institutions in Indonesia. PT. XYZ is a consumer finance company that holds a business license as a non-banking financial institution issued by OJK. It engages in multipurpose financing, and one of its products is hire purchase. This is a type of financing without collateral. The financing application can be submitted, along with copies of an identity card and pay slips, at the counter of any merchant associated with PT. XYZ. Due to the consumer financing demand, the data will be checked, and the application results given within a maximum of $2 \times 24$ hours [3].
From the income statement of PT. XYZ's income statements show that the accounts receivable account affects the company's earnings, which decrease every year. One of the causes of the high value of bad debt is the company's lack of management in the credit monitoring and collection system. This can be proved by the percentage of uncollectible receivables in the company's revenue, which increases every year. Bad debts should be identified and mitigated by the company's risk management so as to reduce their number. One form of risk management that a company can apply is an internal control system for the monitoring and collection of accounts receivable. The internal control system is a tool, method, and means aimed at maintaining the security of corporate property [4]. The tools of this internal control include the appropriate organizational structure and Standard Operating Procedure (SOP), which clearly describe the timing and function of billing activities [5].

To support the internal performance of control in preventing the occurrence of non-performing loans that lead to inefficiency in the procedures for collection of accounts receivable, an internal control system is required [6]. The internal control system is a tool, method, and means aimed at maintaining the security of corporate property [7]. With adequate control, it is expected that the collection process will run smoothly and can minimize the value of bad debts. The output of this research is the evaluation of the organizational structure, time, and function of the billing team, and the billing SOP of PT. $X Y Z$. The findings are expected to be useful for improving the effectiveness of internal control at the company.

Previous researchers have analyzed finance companies. The difference or uniqueness of this study compared with others lies in its focus on internal control. Researchers have examined the risk of receiving credit that focuses on the classification of acceptance/rejection of credit applications $[8,1]$ or on credit card financing products $[4$, 9], while this research focuses on the internal control of collateralized financing receivables. 


\section{B. Research Questions}

Based on the background described above, the discussion of this research is based on the following questions:

- Is the organization structure of the collection department at PT. XYZ appropriate for performing its function?

- Are the time and function of collection accounts receivable at PT. XYZ in accordance with the theory of risk management and internal control?

- Does the billing procedure at PT. XYZ comply with risk management practices?

\section{Research Methodology}

This study uses a qualitative approach with a descriptive research method, by comparing the actual condition of internal control for the monitoring of receivables with conditions that should be achieved based on Romney [5], Mulyadi [10], and a consumer finance company used for comparison. The unit of analysis is a single object, that is, PT. XYZ, while the research instruments are observations and interviews.

\section{Outline of the Study}

\section{1) Introduction}

This chapter provides an overall picture of the study, which consists of the background, research questions, research methodology, and systematic research.

\section{2) Literature Review}

This chapter describes the theories used in the research, for example, concerning the definition of credit, credit collection, risk management, internal control system, and SOP.

\section{3) Methodology}

This chapter provides the methodology used in this study.

4) Analysis and Discussion

This chapter contains an analysis and discussion of the collection department structure and thetimingand function of the collection team for receivables at PT. XYZ.

\section{5) Results}

This chapter presents the research conclusions and suggestions for improvement to PT. XYZ to improve its organizational structure as well as the timing and function of the collection team for receivables.

\section{LITERATURE REVIEW}

A. Credit

According to the Financial Accounting Standards (2013:114) [11], credit is borrowing money based on a loan agreement or agreement between one party and another requiring the borrower to repay his debt after a certain period of time with interest, rewards, or profit sharing. Broadly speaking, there are two types of credit based on the nature of the guarantee, namely, credit with collateral and credit without collateral. Loans with collateral are financing with a guarantee whose value is at least equivalent to the financing. Financing agreements that lack this are loans without collateral, such as hire purchase financing.

\section{B. Credit Policy}

There are three policies in crediting: customer selection standards, credit limits, and billing policies [5]. The credit terms of the credit period and billing policy are procedures that specify the time and manner of billing so that customers pay on time. For example, policies might include calling the customer one day after the billing deadline is missed, sending a letter seven days after, or submit the billing affairs to the collector field after one month.

\section{Credit Billing}

Credit billing is included into the cash receipt cycle in the accounting information system. The billing cycle should be well designed to provide adequate controls and to ensure the company's objectives can be achieved. Table I shows some of the threats and controls for billing receivables by Romney [5]:

TABLE I. THREATS AND CONTROLS FOR BILLING RECEIVABLES

\begin{tabular}{|c|c|c|}
\hline Activity & Threats & Controls \\
\hline $\begin{array}{l}\text { Billing } \\
\text { Receivables }\end{array}$ & $\begin{array}{l}\text { 1. Negligence of payment } \\
\text { 2. Receivables cannot be collected on time } \\
\text { 3. Collaboration between the team of collectors } \\
\text { and consumers } \\
\text { 4. Incorrect entry of receivable update data }\end{array}$ & $\begin{array}{l}\text { 1. Pre-due reminder call and improved tone on each level } \\
\text { of billing } \\
\text { 2. Separation of reminder and billing functions } \\
\text { 3. Job and list rotation. } \\
\text { 4. Periodic reconciliation of receivables and cash received }\end{array}$ \\
\hline Cash Collection & Cash theft / Lapping & $\begin{array}{l}\text { 1. Money paid by consumers to collectors should not be } \\
\text { cash } \\
\text { 2. Separation of duties between collector and receiver of } \\
\text { bills }\end{array}$ \\
\hline
\end{tabular}




\section{Distribution of Billing Functions}

\section{1) Secretariat Function}

This function is responsible for receiving checks from customer payments and sending remittance advice to customers.

\section{2) Billing Function}

This function is responsible for billing corporate debtors based on the list of collected receivables made by the company's system team.

\section{3) Field Billing Function}

This function is responsible for direct billing to consumers in the field. It should not receive money directly from consumers in cash.

\section{E. Cash Collection Procedure}

Before making a direct billing to the consumer, the company creates a list of consumer names to be billed. The list is created by the system part of the company. company secretariat functions sends a reminder letter of responsibility that can bring the consumer to the company. The summons will be sent to each considium at least seven days before the maturity date [10]. Furthermore, the billing function processes payments that are on time. The browser part invites consumers through the phone, unlike at the time of playback by mail. The reminder function calls the consumer the first time when the consumer has not reached the maximum of seven days past the deadline.

When the consumer still has not made the payment 14 days after the deadline, then the biller makes a call with a firmer tone. If the consumer is still delinquent in his obligations 21 days after the due date, then the conversation section performs all three tasks with a very precise and accurate tone. Every conversation that the billing team has with the consumer should be recorded and a report should be made on the results of the talks. Figure 1 is a flowchart of the liability billing procedure.

Once it has beenzstempletes the pillling section of the

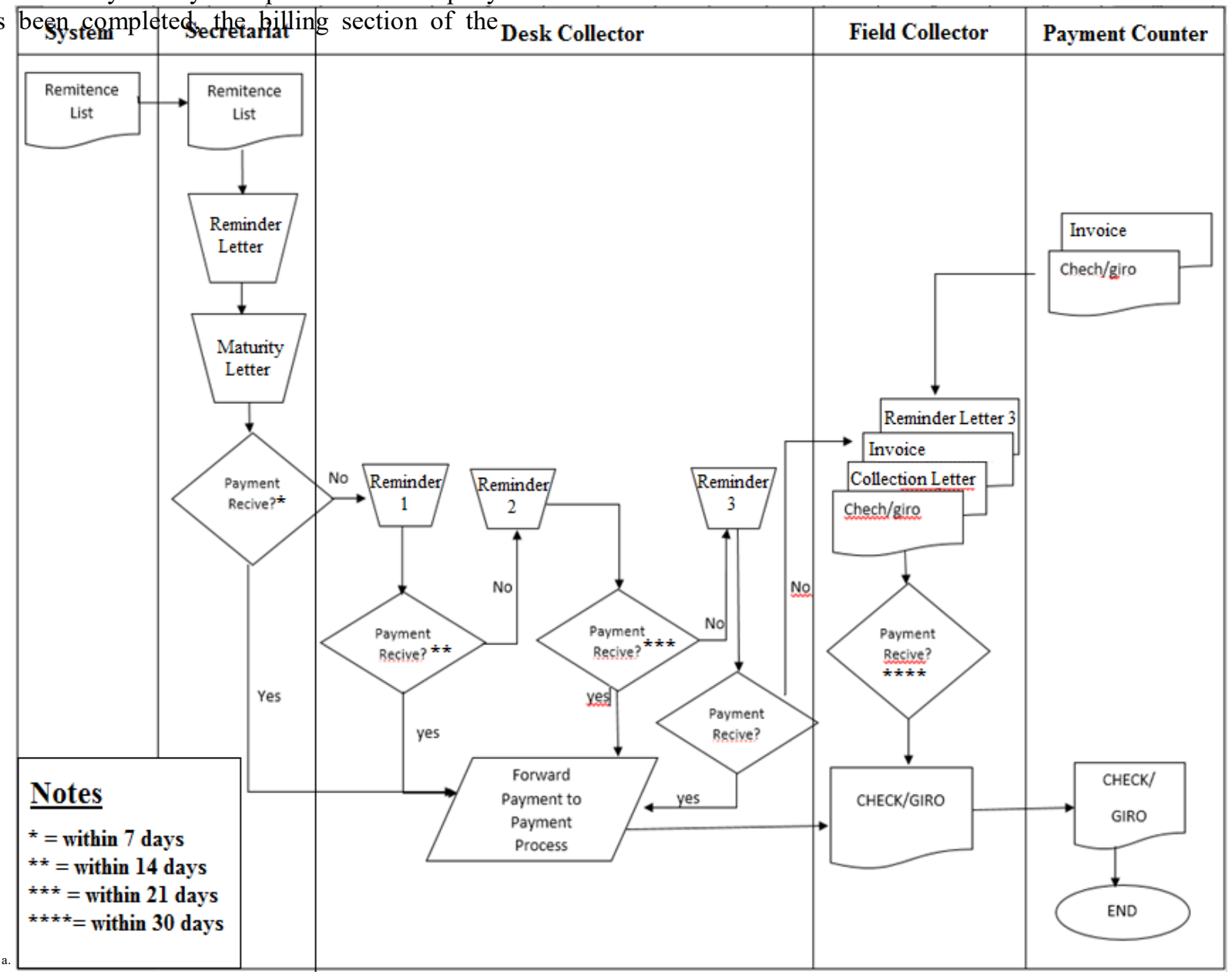

Fig. 1. Flowchart of the Liability Billing Procedure

\section{F. Credit Risk}

In the credit distribution, there must be a credit risk faced by the finance company that is the default risk. In short, credit risk is the risk of loss for finance companies because consumers do not pay off or make the repayments that they should. In fact, the risk of loss, also called credit risk, is a reasonable risk because it is related to the core business.

\section{G. Risk Management}

According to Moller [14], risk is a possible outcome that deviates from the expected. Therefore, it must be managed properly. One way is to build risk management. According to Moller [14], the basic framework in determining the steps to perform risk management for a company's operations is as shown in Figure 2. 


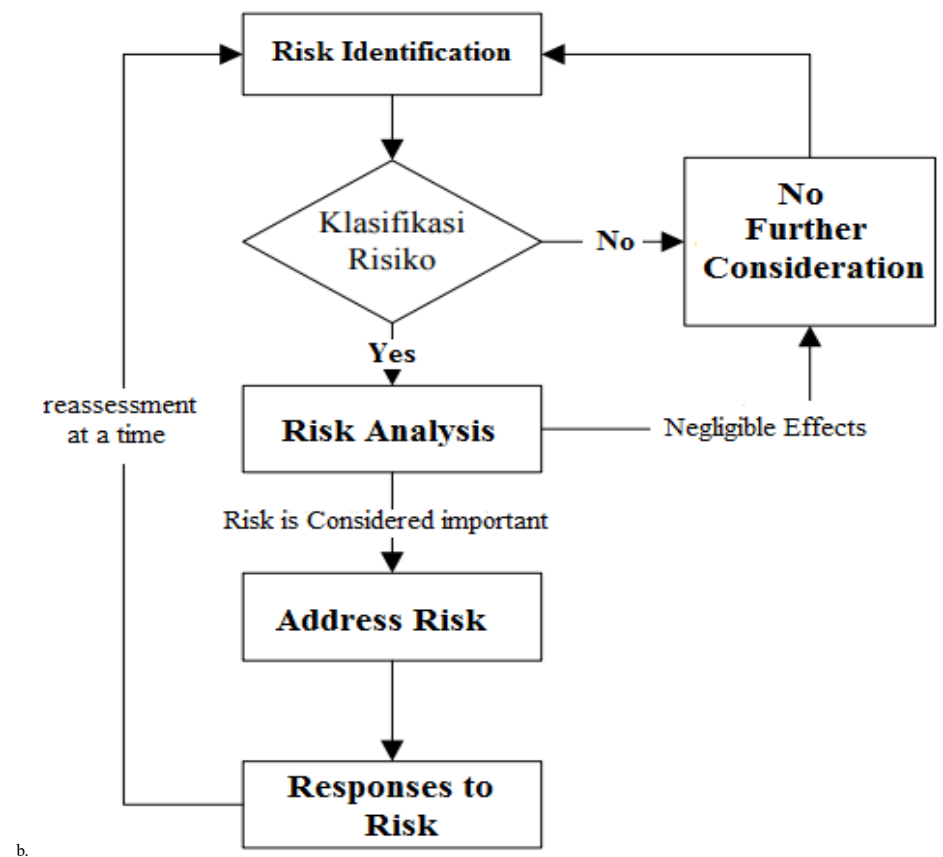

Fig. 2. Steps to Perform Risk Management for Company's Operations

\section{H. Risk Assessment}

According to Moller [14], the value of risk is determined as the multiplication of the frequency (likelihood) with the consequences of risk. Frequency is the magnitude of the chance of loss. The frequency scale can be described as follows in Table II.

TABLE II. FREQUENCY SCALE FOR THE VALUE OF RISK

\begin{tabular}{|l|l|}
\hline Frequency Rate & Scale \\
\hline Very often & 5 \\
\hline Often & 4 \\
\hline Sometimes & 3 \\
\hline Rarely & 2 \\
\hline Very rarely & 1 \\
\hline
\end{tabular}

Consequence is a value that states the probability of occurrence of the event as a risk, and the provisions of the magnitude of the consequences are as shown in Table III.

TABLE III. FReQuenCy SCALE FOR MAGNitude OF CONSEQUENCE

\begin{tabular}{|l|l|}
\hline Frequency Rate & Scale \\
\hline Very large & 5 \\
\hline Big & 4 \\
\hline Medium & 3 \\
\hline Small & 2 \\
\hline Very small & 1 \\
\hline \multicolumn{2}{|l}{ Source: Moller (2013). }
\end{tabular}

Information that explains the risk assessment can be gained from experience, knowledge, and data. If the data are not sufficient to determine whether a risk is large or small, further examination is needed to explain the results of the assessment. The analysis of risk acceptability is determined based on the risk value obtained from the multiplication of likelihood with risk consequence. According to Moller [14]assessment of risk acceptance levels are as follows in Table IV.
TABLE IV. RISK ACCEPTANCE LEVELS

\begin{tabular}{|l|l|}
\hline Risk Acceptance & Acceptance Scale \\
\hline Not acceptable & $>12$ \\
\hline Not expected & $5<-\leq 12$ \\
\hline Acceptable & $2<-\leq 5$ \\
\hline Can be ignored & $\leq 2$ \\
\hline Source: Moller (2013).
\end{tabular}

\section{Internal Control System}

Mulyadi [10] explains that the internal control system is a plan that includes the organizational structure, methods, and tools used in the company with the aim to maintain the security of corporate property, check the accuracy and correctness of accounting data, encourage efficiency, and help encourage compliance with established management policies.

\section{J. Standard Operating Procedure}

Each organization has its own pattern and mechanism in carrying out its activities. The pattern emerges through procedures and guidelines. A procedure is a set of methods of doing a job [5]. Meanwhile, an office procedure is the sequence or steps of implementation of the work. According to Romney et al. [5], work procedures are a series of interrelated tasks and are chronologically sequential in order to complete a job. One form of working procedure is SOP. According to Thomas [2], SOP is a detailed work for all employees to carry out the job as well as possible in accordance with the mission, vision, and purpose of an institution, agency, or institution.

\section{METHODOLOGY}

The research was conducted using a qualitative approach based on a descriptive research method. The 
object of this research is a single object, namely, the controlling system of receivable billing at PT. XYZ. Consideration of PT. XYZ as the object of research is based on the characteristics of the company in accordance with the theme of this study.

\section{A. Data Collection}

The data collection was carried out using a qualitative method with a case study approach, that is, by the observation of documentation and interviews. The data include both primary and secondary data. The secondary data are the company's annual financial statements. The primary data were collected through observations of documentation and interviews. Observations were carried out first to identify the research problem. The main observation activities focused on identifying factors that influenced the research problem [14], namely, the lack of internal control of the company that causes uncollected receivables to continue to increase every year. Observations were conducted in the division that conducts the activities of monitoring and collection of accounts receivable, and billing process in the field. To make the observations, the researchers visited each division of PT. $\mathrm{XYZ}$ involved in the collection process for receivables.

The observations were made to determine the actual condition of current credit collection and to compare it with the theory and practice of operational activities by a multipurpose financing company [14] with the highest liquidity rating in Indonesia according to the statistical data presented on the OJK website. A researcher interviewed the company present to ask about the operational activities of the receivables and made a comparison with PT. XYZ. Interviews were done face-toface with the billing team.

\section{B. Data Processing and Analysis}

From the observational analysis data, the company's policies and guidelines in the collection of accounts receivable was evaluated. The observations of billing activities include an analysis of the functions and tasks of the billing staff. Observations were also undertaken to determine the follow-up activities performed by the billing division staff during a case or problem in the billing process until the problem was addressed (Johnson, 2017). If there was a case in billing, it was observed how long the handling process took, who was involved in the handling of the case, and what procedures were used to resolve the case.

\section{ANALYSIS AND DISCUSSION}

\section{A. Organizational Structure Analysis}

From the description of the implementation of the current organizational structure in PT. XYZ, the researchers assessed the existence of the risk of control where the receivables could not be collected on time. This can happen because based on the current organizational structure, there is no regular communication of programs designed by marketing, where the program will have an impact on the value and procedure of collection of receivables that must be billed by the billing department to the consumer. From the analysis of PT. XYZ's internal data, the researchers also found that within the last few years, there had been feuds between the marketing and billing teams on programs that were designed by marketing, and such incidents occurred about two or three times per year. The researchers assessed the likelihood of risk as 4 (often) and consequently 5 (very large), so the value of the risk was 20 , which is unacceptable. Unacceptable means there is a need for good internal control over this activity in order to minimize the risks contained in it.

In terms of tackling the risk of miscommunication between the marketing and billing departments, it is well known that the marketing department's main job is to focus on selling, regardless of whether the program will negatively impact the operational activities of the billing department. The research comparison showed that one way to minimize the risk so that good supervision takes place is to hold a weekly meeting between the marketing, billing, and risk departments. Therefore, the researchers suggest that PT. XYZ institute a weekly meeting. When the marketing department describes marketing programs, the risk department must play an active role in calculating the impact of the program and whether it falls within the limits of tolerance of the company or not.

In PT. XYZ's current organization structure, the same team that sends reminders also collects the receivables. There is no separation of tasks, as both tasks are done by the desk collector function. Combining the functions of reminder and billing into one is contrary to the theory put forward by Mulyadi [10], that there should be a separation of duties between reminders and bill collectors. In recent years, according to internal data of PT. XYZ, there was a case where the collection team staff did not collect from a customer because they thought the customer had already been billed when in fact it was only a reminder that was sent. The same incident occurred twice in the last two years. Based on the data, the likelihood of this risk was assessed as 3 and consequently 2 . The assessment of the risk is thus 6 , which means "not expected. "The impact of this risk is not very significant to the collection of accounts, but it has an effect on the efficiency of billing at PT. XYZ. Therefore, a recommended is to create a separation of the duties of the collector and the reminder.

Apart from the risk of uncollectible collection of timely receivables, there is also the risk of misuse of authority that will have an impact or cause fraud (conflict of interest) that can be done by the billing department at PT. XYZ. It is known from the organizational structure that in addition to collecting, the collection department is authorized to determine the value of the write-offs that will be posted on the company's books by the firm's accounting team. The basis of the billing department in determining the write-off amount is based on the profiling or the ability to pay consumers who do the billing. If at the moment the consumer claims to be able to pay, then the value of receivables from consumers will not be in write-off. In addition to determining the writeoff value, the billing department has the authority to withdraw goods from a consumer who fails to pay, auction, and determine the pricing of the billing item. Given that the billing department has three responsibilities, the likelihood of this risk is 5 and the 
consequence is 5 , meaning the assessment of the risk is 25 , which means it is unacceptable. Unacceptable means this risk greatly affects the effectiveness and efficiency of the company, so it should be controlled. It is recommended that the collection department be responsible only for the collection of accounts receivable, other activities such as write-offs, and only limited submission of proposals, which will then be reassessed by the accounting team, while the planning and development of bidding items should be removed from the responsibility of the department billing.

\section{B. Time Collection Analysis}

Concerning billing in the field, PT. XYZ only does field visits after three months of late payment. According to the research comparison, this is too long and will affect the value of time and installment money that should be paid. Therefore, it is recommend that PT. XYZ send afield collector after one month of late payment for nominal material, but this is not necessary in other cases, given the operational costs of sending a field collector.

\section{Analysis of Cash Collection Function}

\section{1) Pre-due Reminder bythe Secretariat Function}

PT. XYZ mitigates the risk of negligent payment by consumers by sending a pre-due reminder in accordance with what is suggested by the theory, but the pre-due reminder is sent by the billing section because PT. XYZ does not have a secretariat function in the collection section. It is recommended that PT. XYZ create a new function in the collection department called the secretariat function (this is also recommended in relation to the organizational structure).

\section{2) Receivable Billing}

TABLE V. RISK AND CONTROL ELEMENTS

\begin{tabular}{|c|l|l|l|}
\hline No & Risk & Control Elements & $\begin{array}{l}\text { PT. } \\
\text { XYZ }\end{array}$ \\
\hline 1. & Fraud / cooperation & Job and List Rotation & Done \\
\hline 2. & Less documentation & Talk records & Not Yet \\
\hline 3. & $\begin{array}{l}\text { Negligence of } \\
\text { payment }\end{array}$ & Tone level of the billing & Not Yet \\
\hline 4. & Operational & Daily event news & Not Yet \\
\hline
\end{tabular}

PT. XYZ has the job and list rotation on the billing function. However, it has no policies or tools for recording a billing team discussion with consumers. At the time of the data collection, in the last three years there had been four cases where consumers did not admit they had promised to make payments on a previous billing. The company did not have recordings of the consumer's promise. Because of such incidents, the researchers assessed the likelihood of this risk as 3 and the consequences as 3 , so the assessment of the risk is 9, which means "not expected." It is recommended that the company record all the talks on the billing team for billing level two upwards.

The next risk is that PT. XYZ does not increase the tone at the time of collection to mitigate consumer default risk. At each billing level, consumers are billed in the same manner. Therefore, the likelihood of risk is assessed as 3 and the consequences as 3, so the assessment of this risk of 9, which means "not expected". This means the risk has a negative effect on the activity of collection of accounts receivable at $\mathrm{PT}$. XYZ, so the company is advised to create a control for those risks. It is recommended that the company increase the tone of voice at each level of billing. This is also in accordance with the results of the research comparison, which showed companies create a billing strategy by making a list of sentences that may be spoken for each level of billing.

The next risk is operational risk in the absence of the making of event news after the billing to the consumer. Since the event news is done at the end of the month only, this can increase the risk that the consumer will forget what was talked about on the phone, and there is no record of the talk. It is recommended that PT. XYZ to make a daily news report directly after the collection team finishes billing a consumer. In addition, the event news allows the company to know the latest developments of its customers on a daily basis. Whenever a company official needs an update for each customer, the billing team can present it without having to wait for the end of the month.

Moreover, the analysis revealed obstacles that occur in the field concerning nominal billing to consumers. When a consumer has been in arrears two months or the collection of receivables has entered the second month or longer, the amount of receivables that are charged to the consumer is no longer as big as the agreement at the beginning of the provision of financing but instead follows the value of receivables recorded in the book value or accounting data of the company. In each accounting period, the accounting firm provides the nominal receivable recorded according to the accounting bookkeeping to the collection party. When the financing is approved by the company, the consumer also agrees on how the bill or credit or monthly installments will be paid. Therefore, it is recommended that the collecting team collect in accordance with the original financing agreement.

\section{a) Field Billing by the Field Collector}

The field collectors are permanent employees of PT. $\mathrm{XYZ}$, or in-house field collectors. This means the company has minimized the risk of data theft by a third party. Further, the field collectors are given training on billing procedures in the field as recommended by Bank Indonesia as well as the Financial Services Authority. However, payments in the field are taken in the form of cash. This is contrary to the theory and results of the research comparison, which indicate there is a threat of cash theft or lapping when collecting receivables in the 
field and the payment is made in cash [5]. According to PT. XYZ's internal data, four cases of theft of money by field collectors occurred during the last two years. PT. $\mathrm{XYZ}$ allows payments made by consumers to the field collection team in cash, so based on the analysis, the researchers assessed that the likelihood of this risk is 5 and the consequence is 5; then, the assessment of this risk is 25 , which means it is unacceptable. This is the highest level of risk and cannot be tolerated because it will have a significant impact on the effectiveness of company operations. continues to increase each year. The increase in the value of bad debts is caused by a lack of control of operational activities in terms of the collection of receivables at PT. $\mathrm{XYZ}$ and this materially affects the liquidity of PT. XYZ. This study evaluated whether the collection system of accounts receivable at PT. XYZ is implemented in accordance with the theory and findings of research comparisons of risk management and control of finance companies that are similar to PT. XYZ, which has the highest asset ownership in Indonesia. Based on the results of the discussion and analysis, the conclusions of this study are as follows.

TABLE VI. CONTROL ELEMENTS ASSOCIATED WITH RiSK

\begin{tabular}{|l|l|l|l|}
\hline No. & Risk & Control Elements & PT. XYZ \\
\hline 1. & Theft of consumer data & In-housefield collector & Done \\
\hline 2. & Money theft & Non-cash payment & Not yet \\
\hline 3. & $\begin{array}{l}\text { Delays of money } \\
\text { handover }\end{array}$ & $\begin{array}{l}\text { Field billing letter made by supervisor and confirmation of the minutes of the } \\
\text { event discussed in daily meetings and sampling to test the truth of the event }\end{array}$ & Not yet \\
\hline
\end{tabular}

Therefore, the recommendation is to change the method of payment in the field from cash to checks or deposits directly into the company account through the bank or ATM closest to the consumer's residence.

In addition to money theft, there is also the risk of delayed deposits. When the field collector field goes to collect a bill, the billing letters are created by members of the billing team and billing event reports are also given to members of the billing team. These circumstances may indicate the creation of fraud risk or cooperation between billing team members and field collectors, such that fraud may take the form of maximizing personal gain. Fraud could happen easily because both activities are done by one department without any monitoring from other departments. Based on the current state of the company, the likelihood of this risk is 5 and the consequence is 5 , so the assessment of the risk is 25 , which is unacceptable. This means that the risk will have a negative effect on the operation of the company so that there is a need for proper control. Therefore, it is recommended that PT. XYZ assign the task of creating the billing letter for the field (currently made by the partner in the billing section) to the billing supervisor, and the billing statement should be submitted and directly discussed along with input by several representatives of every department of operations every day. Moreover, the news should be confirmed by contacting a sample of consumers and verifying the information on the incident in the field. These recommendations are in accordance with the results of the research comparison. All activities, including letter billing envoys in the field and the billing statement, must be changed in SOP in accordance with the suggestions above.

\section{RESULTS}

Research on the evaluation of the collection system of receivables on financing without collateral at PT. XYZ was carried out because according to the company's internal data, the value of bad debts at the company
The organizational structure of PT. XYZ is not in line with the theory put forward by [10], [5], and the findings of the research comparison of controlling the risk of collection of accounts receivable. Here are the criteria that are currently not executed by PT. XYZ: There is no oversight to monitor cause and effect rather than company product marketing and billing; there is an absence of the secretariat functions of the billing department; and there is no separation of duties. The billing department has the authority to seize, set pricing, and conduct auctions on the billing items of the defaulted consumer.

Billing time at PT. XYZ is not in line with the theory put forward by [10], [5] and the findings of the research comparisons of controlling the risk of collection of accounts receivable. The time of reminder and time of billing in the field are done by the field collector. The function of billing at PT. XYZ is not in line with the theory put forward by [10], [5], and the findings of the research comparison of controlling the risk of collection of accounts receivable. Here are the criteria that are currently not executed by PT. XYZ: The company has not prejudged the three functions of the billing cycle to consumers, namely, the secretariat, the collection department, and the billing section; it has not created documentation in the form of voice recordings of the conversationsheld by the team of collectors with consumers; there is no SOP that confirms an increase in voice or tone at each billing level by the collection team; and the nominal value collected by the nominal collection team follows the nominal of bookkeeping or accounting of the company, in which the allowance for doubtful accounts is recognized. No risk management has been undertaken for theft or delay in depositing the money received by field collectors in the field (consumers may make

cash payments). 


\section{REFERENCES}

[1] Central Bureau of Statistics. (2016). Financial Institution Statistics 2016 (https://bps.go.id/)

[2] Thomas, LC. 2010. Consumer Finance: Challenges for Operational Research. Journal Of The Operational Research Society 61, 41-52.

[3] PT. XYZ. 2013. Organizational Structure and Operations of PT. XYZ.

Robbins, Judge. (2007). Organizational behavior $2^{\text {nd }}$ ed. Jakarta: Salemba Empat

[4] Butaru, F., Chen, Q., Clark, B., Das, S., Andrew, W.L., \& Akhtar, S. (2016). Risk and risk management in the credit card industry. Journal of Banking and Finance, 72 (2016), 218-239.

[5] Romney, Marshal, \&Seinbart. (2016). Accounting Information System $12^{\text {th }}$ ed.

[6] Mardiyanto, H. (2010). Digest of Financial Statements. Jakarta: Grasindo.

[7] (Maurice et al., 2014

[8] Baesens, B., Setiono, R., \&Mues, C. (2003). Using neural network rule extraction and decision tables for credit-risk evaluation. Mngt Sci 49,312

[9] Kosmas, N. (2009). The Impact of Effective Credit Risk Management On Bank Survival. Journal Annals of the University of Petosani, Econimics, 9(2), 173-184.

[10] Mulyadi. (2015). Accounting System. 4th ed. Jakarta: Salemba Empat.

[11] Financial Accounting Standards. (2013). Jakarta: Salemba Empat

[12] Moller, R. R. (2013). COSO Enterprise Risk Management: Understanding The New Integrated ERM Framework5th edition. John Wiley \& Sons Inc.

[13] Sugiyono. (2016). Quantitative, qualitative and R \& D Research Methodology. Jakarta: Alfabeta

[14] Sekaran, U., \& Bougie. R. (2011). Research Methods for Business: A Skill-Building Approach. Fifth Edition. USA: Wiley. 